\title{
ANALISA KONSEPTUAL MODEL SPIRITUAL WELL-BEING MENURUT ELLISON DAN FISHER
}

\author{
Raja Oloan Tumanggor \\ Fakultas Psikologi Universitas Tarumanagara Jakarta \\ rajat@fpsi.untar.ac.id
}

Masuk :15-04-2019, revisi: 09-09-2019, diterima untuk diterbitkan : 09-09-2019

\begin{abstract}
ABSTRAK
Studi ini menganalisa lebih dekat dua model spiritual well-being (SWB) yang dikembangkan oleh Craig W. Ellison dan John W. Fisher. Dengan menggunakan metode kualitatif kepustakaan dilakukan perbandingan (komparasi) secara deskriptif antara pendekatan Ellison dan Fisher. Ellison memperkenalan model spritual well-being dengan dua dimensi, yakni religious well-being (RWB) dan existential well-being (EWB). Berdasarkan kedua dimensi itu Ellison kemudian mengembangkan alat ukur Spiritual Well-being Scale (SWBS). Sementara Fisher menampilkan model SWB dengan empat dimensi, yaitu personal, komunal, mondial dan transendental. Berangkat dari empat dimensi ini Fisher mengembangkan juga alat ukur Spiritual Well-being Questionaire (SWBQ). Ellison dan Fisher mendalami spiritual well-being bertolak dari pengalaman mereka mendampingi kehidupan spiritual jemaat yang mereka layani. Ellison memahami spiritual well-being sebagai kesejahteraan rohani yang merupakan perwujudan konkrit dari kesehatan rohani, sedangkan Fisher melihat spiritual well-being sebagai afirmasi hidup manusia dalam hubungannya dengan diri sendiri, sesama, lingkungan dan Tuhan. Fisher memiliki dimensi spiritual well-being lebih terperinci dari pada Ellison. Jadi perbedaan konsep dan dimensi spiritual well-being model Ellison dan Fisher berdampak kepada pembentukan alat ukur yang berbeda juga atas kedua model Ellison dan Fisher. Kendati ada perbedaan konsep dan dimensi spiritual well-being model Ellison dan Fisher, namun keduanya diperlukan untuk memperoleh pemahaman lebih mendalam atas model spiritual well-being.
\end{abstract}

Kata-kata kunci: spiritual well-being, religious well-being, existential well-being, model, pemahaman.

\section{ABSTRACT}

This study analyzes more closely the two models of spiritual well-being (SWB) developed by Craig W. Ellison and John W. Fisher. By using qualitative literature method a descriptive comparison was made between the Ellison and Fisher approaches. Ellison introduced the spiritual well-being model with two dimensions, namely religious wellbeing (RWB) and existential well-being (EWB). Based on these two dimensions Ellison then developed the Spiritual Well-being Scale (SWBS) measurement tool. Meanwhile, Fisher explained SWB model with four dimensions, namely personal, communal, mondial and transcendental. From these four dimensions, Fisher developed the Spiritual Wellbeing Questionnaire $(S W B Q)$ measurement tool. Ellison and Fisher examined spiritual well-being based on their respective experience accompanying the spiritual lives of the congregations they served. Ellison understood spiritual well-being as a concrete manifestation of spiritual health, while Fisher sees spiritual well-being as an affirmation of human life in relation to oneself, others, the environment and God. Fisher explains spiritual dimension of well-being in more detail than Ellison. Therefore, the different concepts and spiritual well-being dimensions of Ellison and Fisher's models have an impact on the formation of different measurement tools than both Ellison and Fisher's models. Despite the differences in the concepts and dimensions of the spiritual well-being models of Ellison and Fisher, both are needed to gain a deeper understanding of the spiritual well-being model.

Key words: spiritual well-being, religious well-being, existential well-being, models, understanding.

\section{PENDAHUluaN \\ Latar Belakang}

Pada tahun 60an dan 70an gerakan indikator sosial (social indicators movement) diprakarsai oleh pemerintah Amerika sebagai satu metode untuk mengukur kualitas hidup di negara itu. Indikator seperti pendidikan, pendapatan, kesehatan, sandang dimonitor dengan seksama. Hasilnya menunjukkan adanya peningkatan dalam kualitas hidup. Kendati indikator objektif menunjukkan hal positif, namun pada saat yang sama terjadi alienasi sosial dan politik, penggunaan narkoba 
dan problem keluarga juga meningkat. Ada kesadaran bahwa kepuasan dalam hidup tidak tergantung pada faktor objektif saja. Serangkaian indikator negatif dan positif dari subjective well-being pun dikembangkan, termasuk mengukur afeksi positif dan negatif, kebahagiaan dan kepuasan hidup (Bufford, Paloutzian, \& Ellison, 1991). Pada saat yang sama gerakan quality of life memandang pentingnya spiritualitas dalam well-being.

Ellison (1983, Paloutzian \& Ellison, 1982) berpendapat bahwa kualitas hidup dapat dikonseptualisasikan untuk mengembangkan material, psychological dan spiritual well-being. Namun literatur yang mengulas kualitas hidup kerap mengabaikan dimensi ketiga (spiritual wellbeing) yang menekankan aspek transendental. Itulah sebabnya Ellison merancang Spiritual WellBeing Scale (SWBS) untuk menjawab kekosongan itu.

Pada 1975 The National Interfaith Coalition on Aging (NICA) telah merekomendasikan bahwa spiritual well-being merupakan afirmasi hidup yang berhubungan dengan diri sendiri (personal), orang lain (others), alam (environment), dan Tuhan (transenden yang lain). Mengintegrasikan konsep ini secara bersama-sama, maka spiritual well-being dapat didefenisikan sebagai "Pernyataan tentang ada yang merefleksikan perasaan positif, tingkah laku dan pemahaman relasi dengan diri sendiri, orang lain, transenden, dan alam, yang pada gilirannya menampilkan individu dengan identitas, keseluruhkan, kepuasan, kegembiraan, cinta, respek dan sikap positif, harmoni dalam hidup (Gomez \& Fisher, 2003).

Dengan menggunakan keempat domain yang diusulkan oleh NICA (1975) yaitu diri sendiri (personal), orang lain (komunal), alam (lingkungan) dan Tuhan (yang transenden), Fisher pada tahun 1998 menginterview 98 guru sekolah menengah pertama mengenai apa yang mereka kira menjadi indikator penting bagi kesejahteraan spiritual untuk anak didik mereka (Gomez \& Fisher, 2003). Interview menggunakan pertanyaan yang direfleksikan dalam sejumlah pengukuran spiritual well-being. Disini Fisher mengacu pada beberapa alat ukur seperti Spiritual Well-being Scale dari Ellison (1983), the Spiritual Orientation Inventory dari Elkins et.al. (1988), the Mental, Physical and Spiritual Well-Being Scale dari Vella-Brodrick \& Allen (1995), the Spiritual Assessment Inventory dari Hall \& Edwards (1996), the Perceived Wellness Survey dari Adams et.al.(1997), dan the JAREL Spiritual Well-Being Scale dari Hungelmann et.al. (1996).

Dari penelitiannya Fisher (1998) menyimpulkan bahwa spiritual well-being merefleksikan keluasan dimana manusia hidup dalam harmoni melalui relasi dengan diri sendiri (personal), orang lain (communal), alam/lingkungan (environmental) dan Tuhan (transcendental). Dari situ Fisher kemudian mengembangkan model spiritual well-being dengan menerbitkan The Spiritual Well-Being Questionnaire (SWBQ) pada 2003. Alat ukur ini dikembangkan untuk mengukur empat dimensi spiritual well-being yang sudah diujicoba oleh Fisher (1998). Alat ukur terdiri dari 20 pertanyaan dimensi yang berbeda seperti personal, communal, environment dan transcendental spiritual well-being, dengan masing-masing 5 pertanyaan untuk setiap dimensi (Gomez \& Fisher, 2005).

\section{Rumusan Masalah}

Namun yang menjadi persoalan adalah apakah yang mendasari munculnya model spiritual wellbeing dari Ellison dan Fisher? Apakah ciri khas dari kedua model dan dimanakah letak perbedaan kedua model Ellison dan Fisher? Apakah dampak perbedaan kedua model ini bagi pemahaman yang lebih komprehensif mengenai spiritual well-being? Dalam studi ini mau digali 
kekhasan dari kedua model SWB dari Ellison dan Fisher dan manfaat apa yang bisa diperoleh dalam pemahaman yang lebih mendalam mengenai spiritual well-being.

\section{METODE PENELITIAN}

Tema penelitian adalah analisa konseptual model spiritual well-being menurut Ellison dan Fisher. Untuk mencapai tujuan penelitian peneliti memakai metode kualitatif deskriptif. Peneliti menganalisa secara kritis berbagai macam model spiritual well-being dari Ellison dan Fisher. Model spiritual well-being Ellison dan Fisher merupakan topik penting dalam penelitian psikologi. Perbedaan konseptual model spiritual well-being dari kedua pakar tersebut hendak dianalisa untuk memperoleh pemahaman lebih mendalam mengenai spiritual well-being.

Pertama-tama diidentifikasi pengertian variabel yang digunakan, lalu dievaluasi secara kritis untuk memperoleh suatu konsep yang lebih utuh (Bakker \& Zubair, 2012). Demikianlah akan diidentifikasi pengertian variabel spiritual well-being beserta model-model yang dimilikinya khususnya dari Ellison dan Fisher. Apa perbedaan model SWB dari Ellison dan Fisher dan apa pula yang mendasari perbedaan tersebut. Kemudian dievaluasi secara kritis perbedaan antara model Ellison dan Fisher, apakah pengaruh pemahaman kedua model SWB terhadap pemahaman atas spiritual well-being. Peneliti mengkaji semua literatur yang ada mengenai model spiritual well-being yang dibahas dari berbagai sumber-sumber kepustakaan, dan menguraikan pokok persoalan tersebut secara deskriptif dan sistematis. Oleh sebab itu dalam penelitian ini, peneliti memakai metode penelitian kepustakaan (library research).

\section{HASIL DAN PEMBAHASAN}

Pada saat ini terjadi minat yang semakin meningkat dalam meneliti hubungan antara spiritualitas dengan keadaan baik (well-being) (Gomez \& Fisher, 2005). Secara tradisional spiritualitas selalu dihubungkan atau disamakan dengan konsep mengenai keagamaan. Banyak diskusi di kalangan para ahli membahas tentang defenisi spiritualitas. Kelly (1995) mendefenisikan spiritualitas sebagai pengalaman subjektif akan aspek transendental alam semesta, sedangkan agama dipahami sebagai ekspresi rohani dan institusional atas spiritualitas. Spiritualitas dilihat sebagai sebuah pengalaman universal, sementara doktrin dikaitkan dengan agama tertentu. Reich (1996) dalam Moodley et al. (2012) menyebutkan empat kemungkinan cara melukiskan hubungan antara kehidupan beragama dengan spiritualitas, yaitu pertama, spiritualitas dan agama sinonim, Kedua, spiritualitas ada di bawah agama, Ketiga, agama dan spiritualitas berbeda, keempat, agama dan spiritualitas bersifat distingtif (bisa dibedakan), tapi kadang juga overlapping (saling tumpah tindih).

\section{Pengertian Spiritualitas dan Spiritual Well-being}

Kata 'spiritualitas' berasal dari bahasa Latin spiritus yang berarti nafas, dan umumnya mengacu pada substansi non material dari tubuh manusia. Dalam sejarah manusia spiritual merupakan unsur hakiki dan integral dari hidup manusia baik di tingkat individual maupun sosial. Dari perspektif psikologis delapan tingkat perkembangan model Erikson mengungkapkan bahwa setiap individu, bila sampai ke suatu tahapan tertentu, akan mengajukan pertanyaan berikut, "Apa arti hidupku?" dan "Bagaimana saya merasakan hidupku?" Mencari integritas diri menjadi aspek kunci dari kesehatan perkembangan psikologis. Dari perspektif perkembangan sosial teori mengatakan bahwa saat mengalami proses penuaan setiap individu mengalihkan fokus mereka dari pandangan materialistik ke arah yang lebih kosmis dan transenden. Satu unsur penting untuk meraih pandangan dunia adalah spiritualitas, yang juga dianggap berkontribusi bagi perkembangan positif dalam kehidupan manusia. 
Para ahli dari berbagai bidang termasuk profesional bidang kesehatan dan perawatan berusaha mendefenisikan spiritualitas sebagai suatu makna dan tujuan yang berkaitan dengan perasaan damai dan harapan. Spiritualitas menerjemahkan kebebasan eksistensial manusia mencakup kesadaran individual dengan latar belakang budaya dan agama. Spiritualitas juga menyangkut hal transenden yang mengacu pada keadaan mengatasi ruang dan waktu (Lou, 2015; Kelly 1995). Jadi spiritualitas adalah cara berada dan mengalami yang datang melalui kesadaran akan dimensi transendental dan hal itu dicirikan oleh nilai bagi diri sendiri, orang lain, alam, hidup.

Sementara spiritual well-being adalah sesuatu situasi yang muncul dari keadaan kesehatan spiritual dan tampak melalui ekspresi kesehatan yang baik. Spiritual well-being merupakan indikasi kualitas hidup seseorang dalam dimensi spiritual atau indikasi dari kesehatan spiritual mereka (Ellison, 1983; Bufford, Paloutzian \& Ellison, 1991). Sementara Fisher yang mengacu pada the National Interfaith Coalition on Aging (NICA) di Washington DC mendefenisikan spiritual well-being sebagai afirmasi hidup dalam berelasi dengan Tuhan, diri sendiri, komunitas dan lingkungan secara keseluruhan. Hubungan ini dapat dikembangkan menjadi empat domain yang saling berhubungan dari eksistensi manusia menyangkut kesehatan spiritual (Fisher, 2010).

Keempat domain itu meliputi pertama, domain personal, dimana seseorang berhubungan dengan dirinya sendiri menyangkut makna, tujuan dan nilai dalam hidup. Kesadaran diri merupakan kekuatan yang menentukan atau aspek transendental dari roh manusia dalam mencari identitas diri. Kedua, domain komunal ditunjukkan dalam kualitas dan kedalaman relasi interpersonal antara diri sendiri dengan orang lain, berkaitan dengan moralitas, budaya dan agama. Ini diungkapkan dalam cinta, pengampunan, kepercayaan, harapan dan iman dalam kemanusiaan. Ketiga, domain lingkungan menyangkut pemeliharaan fisik dan biologis, rasa memiliki dan kagum dan gagasan kesatuan dengan lingkungan. Keempat, domain transendental meliputi hubungan diri sendiri dengan sesuatu yang melewati aspek manusia, seperti kepedulian puncak, kekuatan kosmis dan realitas transenden (Fisher, 2011; Fisher \& Ng, 2017).

Konsep mengenai spiritual well-being yang dikaitkan dengan agama memang cukup kompleks. Terminologi spiritual well-being pertama sekali muncul ketika berlangsung konferensi gedung putih mengenai penuaan (White House Conference on Aging) pada 1971 (Fisher, 2016). Pada tahun 1975 The National Interfaith Coalition on Aging (NICA) mendefenisikan spiritual wellbeing sebagai afirmasi hidup dalam hubungannya dengan diri sendiri (personal), orang lain (communal), alam (environment) dan Tuhan (transcendental). Sementara Ellison melihat spiritual well-being sebagai suatu ekspresi yang mendasari kesehatan mental. Ellison membandingkan situasi ini pada beragam corak seseorang dan denyut nadi sebagai ekspresi kesehatannya. Dengan mengkombinasikan rumusan NICA dan Ellison, maka Fisher mendefenisikan spiritual well-being sebagai suatu keadaan merefleksikan perasaan positif, tindakan dan pemikiran akan relasi dengan diri sendiri, orang lain, lingkungan dan hal transenden (Tuhan), pada gilirannya memberikan individu suatu identitas, kepuasan, kegembiraan, cinta, respek, sikap positif, damai batin, harmoni, dan arah hidup (Moodley et al., 2012).

Berangkat dari konferensi pada tahun 1971 dan kemudian pendefenisian spiritual well-being oleh NICA pada 1975, maka Ellison memperkenalkan sebuah model spiritual well-being, yang disebut dengan The Spiritual Well-Being Scale (SWBS). Jadi latar belakang Ellison memperkenalkan model SWBS adalah minat yang semakin tinggi pada masalah kualitas hidup (quality of life) dan keadaan baik subjektif (subjective well-being). Maka, SWBS hadir untuk mengukur dimensi spiritual dari quality of life. Model ini menunjukkan beragam tingkatan dari 
well-being, misalnya masalah fisik, kesehatan mental, persoalan psikologis dan asertif (Bufford, Paloutzian, Ellsion, 1991).

\section{Mengenal Ellison dan Fisher}

Siapakah Ellison? Craig W. Ellison merupakan direktur dari the Alliance Graduate School of Counseling di Nyack, New York. Dia merupakan guru besar bidang Urban Studies dan Konseling di the Alliance Theological Seminary dari 1983-2008. Dia juga berpraktek pribadi sebagai seorang psikoterapis. Ellison merupakan penulis tujuh buku termasuk From Stress to Well-being (Word/Nelson) dan Healing for the City (Zondervan). Ellison juga adalah dewan penasehat nasional dari American Association of Christian Counselors dan editor untuk the Journal of Psychology and Theology. Setiap minggu selama 18 tahun dia menyiar di radio dengan tema perspektif atas kehidupan personal yang disiarkan ke seluruh Amerika. Dia juga adalah pendiri dan sekaligus direktur New Hope Counseling Centers di Metro New York. Ellison adalah penerima anugerah The Alumnus of the Year Award dari King's College (NY), dan penerima Distinguished Member Award dari Christian Association for Psychological Studies. Dia juga penerima Templeton Foundation Award untuk publikasi ilmiah yang menonjol.

Ellison memperkenalkan SWBS dalam publikasinya bersama Paloutzian (1982) dan dalam artikelnya Spiritual Well-being: Conceptualization and measurement (1983). SWBS menampilkan dua dimensi yakni Existential Well-Being (EWB) dan Religious Well-Being (RWB). EWB dan RWB model Ellison ini sebenarnya mengadopsi konsep Moberg mengenai elemen horizontal dan vertikal dari spiritual well-being. Elemen horizontal merefleksikan kepuasan hidup, sedangkan elemen vertikal merefleksikan relasi dengan Tuhan (Ellison, 2006). Masing-masing dimensi diukur dengan 10 pertanyaan. Kedua dimensi itu melibatkan transendensi, dan bergerak melewati realitas. Kendati secara parsial bisa dibedakan, tapi kedua dimensi itu saling mempengaruhi. Dua unsur EWB yaitu arah hidup dan kepuasan hidup mengukur arti, tujuan dan nilai dalam kehidupan. Hal ini hanya berhubungan dengan dimensi personal dari model spiritual well-being dari Fisher. Ellison tidak mempertimbangkan hubungan satu sama lain kedua dimensi tersebut. Alat ukur spiritual well-being model Ellison ini telah sering digunakan dalam penelitian selama bertahun-tahun. Hal ini menunjukkan bahwa reliabilitasnya cukup baik. Model SWBS tampaknya sangat bermanfaat digunakan untuk masalah klinis guna mendeteksi secara signifikan tingkatan well-being (Bufford, Paloutzian, Ellision, 1991; Ellison, 2006).

Jadi pada intinya, alat ukur SWBS model Ellison dikembangkan sebagai indikator umum atas pernyataan subjektif atas religious dan existential well-being. Model alat ukur ini merupakan inventaris laporan diri dan mengharapkan jawaban dari partisipan akan memberikan refleksi kepercayaan pribadi mereka tentang well-being pribadinya. Setiap item menggunakan skala Likert mulai dari angka 1 (sama sekali tidak setuju) hingga angka 6 (sangat setuju) dan tidak ada angka tengah. Penggagas model ini merekomendasikan alat ukur ini digunakan untuk tujuan klinis dan konseling baik secara individual maupun kelompok. Selain itu alat ukur model Ellison ini dapat digunakan oleh para praktisi guna mengidentifikasi kekuatan para klien yang didasarkan pada pengalaman spiritual mereka (Ellison, 2006). Secara ringkas model spiritual well-being Ellison dapat dilihat dalam tabel berikut.

Setelah melihat latar belakang dan kekhasan model spiritual well-being dari Ellison, sekarang mau didalami model yang diperkenalkan oleh Fisher. John Wayne Fisher adalah guru besar di Institute of Health, Medical Sciences \& Society, University of Glyndwr, Wales. Pada 1998 meraih doktor bidang Health Education/Spiritual Health dari University of Melbourne. Selain itu 
dia juga mendapat doktor pendidikan bidang spiritual well-being pada 2009 dari University of Ballarat. Sejak 1993 publikasinya banyak mengulas tentang kesehatan dan kesejahteraan spiritual (health/spiritual well-being). Konsistensinya dalam mendalami spiritual well-being, membuat Fisher termasuk ahli yang patut diperhitungkan dalam pembahasan mengenai spiritual well-being.

Kepedulian Fisher pada spiritual well-being sebetulnya sudah berlangsung sejak lama. John Wayne Fisher adalah seorang pakar yang sejak lama menggeluti masalah pendidikan. Setelah menyelesaikan sarjana di Universitas Adelaide Australia pada 1967 dan meraih diploma dari Adelaide Teachers College pada 1969 Fisher meraih Master of Education dari University of Melbourne pada 1994. Sejak meraih PhD pada 1998 bidang pendidikan kesehatan dan kesehatan spiritual dari Universitas Melbourne, Fisher selalu menggeluti bidang spiritual well-being. Hal itu nampak dari puluhan publikasinya sejak tahun 1990 an hingga kini publikasi Fisher mendominasi bahasan mengenai spiritual well-being. Apalagi pada 2009 Fisher meraih lagi gelar doktor bidang pendidikan (EdD) khusus di bidang spiritual well-being.

Dalam mendefenisikan spiritual well-being Fisher tidak lepas dari gagasan pendahulunya yang sudah mengulas masalah yang sama seperti defenisi yang diungkapkan oleh NICA (1975) dan Ellison (1982, 1983). Fisher mendefenisikan spiritual well-being sebagai " a state of being, reflecting positive feelings, behaviours, and cognitions of relationships with oneself, others, the transcendent and nature, that in turn provide the individual with a sence of identity, wholeness, satisfaction, joy, contentment, beauty, love, respect, positive attitudes, inner peace and harmony, and purpose and direction in life" (Moodley et al., 2012). Berangkat dari empat dimensi dari spiritual well-being yang diperkenalkan oleh NICA (1975) Fisher mengembangkan suatu model spiritual well-being yang disebut dengan The Spiritual Well-Being Questionaire (SWBQ) yang dipublikasikan pada 2003. Fisher sampai pada kesimpulan bahwa kesehatan spiritual merupakan satu keadaan yang dinamis (a dynamic state of being). Manusia dapat hidup penuh harmoni dalam relasi dengan empat dimensi dari spiritual well-being, yakni hubungan dengan diri sendiri (personal), orang lain (communal), alam (environmental), dan Tuhan (transcendental).

Pertama, dalam dimensi personal orang berelasi dengan diri sendiri tentang makna, tujuan dan nilai kehidupan. Roh manusiawi menciptakan kesadaran diri berkaitan dengan self esteem dan identitas. Kedua, dimensi komunal diungkapkan dalam kualitas dan kedalaman hubungan interpersonal antara diri sendiri dan orang lain. Moralitas, budaya dan agama masuk dalam dimensi komunal yang juga melahirkan cinta, keadilan, harapan, dan iman dalam kemanusiaan. Ketiga, dimensi lingkungan (environmental) meluas dari kepedulian pada komponen fisik dan biologis, ke arah kekaguman dan gagasan akan kesatuan dan keterikatan pada lingkungan. Keempat, dimensi transendental mengungkapkan hubungan seseorang pada 'sesuatu' atau keadaan diatas tingkat kemanusiaan seperti kekuatan kosmis, kenyataan transendental atau Tuhan. Hal ini mengandaikan iman akan sesuatu dan juga penyembahan dan ibadah kepada sumber misteri dari alam semesta (universe). Kualitas hubungan pada masing-masing dimensi ini merefleksikan spiritual well-being seseorang.

\section{Perbandingan model Ellison dan Fisher}

Untuk melihat perbandingan kedua model Ellison dan Fisher mengenai spiritual well-being dapat diamati dari tabel berikut ini: 
Tabel 1. Perbandingan model spiritual well-being dari Ellison dan Fisher

\begin{tabular}{|c|c|c|}
\hline Spiritual Well-Being & Model Ellison & Model Fischer \\
\hline Defenisi & $\begin{array}{l}\text { Spiritual well-being arises from an } \\
\text { underlying state of spiritual health } \\
\text { and is an expression of it, much like } \\
\text { the color of one's complexion and } \\
\text { pulse rate are expressions of good } \\
\text { physical health (Ellison, 1983) }\end{array}$ & $\begin{array}{l}\text { Affirmation of life in relationship } \\
\text { with oneself, others, nature, and } \\
\text { God (mengacu pada NICA, 1975) }\end{array}$ \\
\hline Alat Ukur & $\begin{array}{l}\text { The Spiritual Well-Being Scale } \\
\text { (SWBS): } 20 \text { item }\end{array}$ & $\begin{array}{c}\text { The Spiritual Well-Being } \\
\text { Questionaire (SWBQ): } 20 \text { item }\end{array}$ \\
\hline Dimensi & $\begin{array}{l}\text { Existential Well-Being (EWB) } \\
\text { Religious Well-Being (RWB) }\end{array}$ & $\begin{array}{c}\text { Personal (self) } \\
\text { Communal (others) } \\
\text { Environmental (nature) } \\
\text { Transcendental (God) }\end{array}$ \\
\hline Dasar Acuan & $\begin{array}{l}\text { Quality of Life, Subjective Well- } \\
\text { Being, NICA (1975) }\end{array}$ & NICA (1975), Ellison $(1982,1983)$ \\
\hline Diperkenalkan & 1983 & 2003 \\
\hline Bidang Sasaran & Klinis, Konseling & Sekolah, Universitas \\
\hline
\end{tabular}

Secara prinsipil kedua model spiritual well-being Ellison dan Fisher memiliki akar sejarah yang sama yaitu adanya kepedulian dari pemerintah Amerika Serikat pada tahun 70an terhadap proses penuaan masyarakat dan hubungannya dengan kehidupan spiritual. Koalisi Antar Iman Nasional untuk Penuaan (NICA) kemudian memberikan defenisi spiritual well-being sebagai keadaan terjalinnya hubungan yang harmonis seseorang dengan dirinya sendiri, sesama, alam dan Tuhan. Ellison melihat dimensi spiritual perlu dikembangkan dalam konteks peningkatan kualitas hidup (quality of life) dan keadaan baik subjektif (subjective well-being) yang hangat diteliti pada tahun 70an hingga awal tahun 80an. Maka dia mengembangkan sebuah alat ukur yang memiliki dua dimensi, yaitu dimensi eksistensial dan religious dari well-being. Bagi Ellison kesehatan spiritual menentukan keadaan baik spiritual seseorang.

Sementara Fisher berpendapat bahwa spiritual well-being harus dilihat dari berbagai dimensi seperti personal, komunal, lingkungan dan transendental. Penekanan pada empat dimensi ini sebenarnya berasal dari penekanan yang sudah diungkapkan oleh NICA. Hanya saja Fisher selama hampir 30 tahun terakhir secara konsisten menekuni dan meneliti spiritual well-being.

\section{Model-model Spiritual Well-being}

Ellison mengembangkan model spiritual well-being yang disebut dengan The Spiritual WellBeing Scale (SWBS) yang ramai dibahas dalam publikasi antara tahun 1982-1991. SWBS ini memiliki dua dimensi yaitu Religious Well-Being (RWB) dan Existential Well-being (EWB). RWB meliputi hubungan dengan kekuatan tertinggi, yaitu Tuhan. Ini disebut dengan dimensi 
vertikal dari SWB. Sementara EWB merupakan elemen psikososial dan menunjukkan perasaan seseorang terhadap sesamanya. Elemen psikososial ini merupakan dimensi horizontal dari SWB. Kedua dimensi ini terdapat dalam diri manusia (Ellison, 1983; Jafari et al, 2017). Ellison menaruh perhatian pada urusan publik (agama) dan urusan privat (harmoni eksistensial) SWB, maka SWB bagus diukur dari kedua dimensi ini (Ellison, 1983; Eksi \& Kardas, 2017).

Sementara model spiritual well-being dari Fisher memiliki empat dimensi, yaitu dimensi personal, komunal, lingkungan dan transendental. Dimensi personal meliputi aspek pengetahuan yang disaring oleh pandangan dunia. Aspek inspirasionalnya mencakup esensi dan motivasi yang disaraing oleh kepercayaan. Hal yang masuk dalam dimensi personal ini adalah makna, tujuan dan nilai. Dimana roh manusiawi menciptakan kesadaran akan diri sendiri. Semua hal ini diungkapkan sebagai kegembiraan, kepenuhan, damai, kesabaran, kebebasan, identitas, integritas, kreativitas, intuisi dan nilai pribadi. Dimensi kedua adalah komunal yang terwujud dalam moralitas, budaya dan agama. Hal ini tampak dalam hubungan interpersonal yang mendalam untuk mencapai hati manusia. Hal ini diungkapkan dalam bentuk cinta, pengampunan, keadilan, harapan dan iman dalam kemanusiaan, dan kepercayaan. Dimensi ketiga adalah lingkungan yang meliputi kepedulian pada alam dan pemeliharaan fisik dan lingkungan politik dan sosial serta dikaitkan dengan alam ciptaan. Hal ini diekspresikan sebaga rasa kagum dan menilai alam dan ciptaan. Dimensi keempat adalah hal transendental yang mencakup kepedulian tertinggi, kekuatan kosmis dan Tuhan (bagi penganut theistis). Hal ini diungkapkan lewat penyembahan, ibadat pada pencipta, dan keberadaan alam dan sang pencipta (Fisher, 2011; Gomez \& Fisher, 2016).

\section{Pengukuran Spiritual Well-being}

Spiritual Well-Being model Ellison diukur dengan alat ukur Spiritual Well-Being Scale (SWBS) yang dikembangkan sebagai indikator umum dalam menilai kesejahteraan religius dan eksistensial. Dirancang sebagai sarana untuk merefleksikan kepercayaan pribadi. Setiap pernyataan dinilai dari sangat tidak setuju (skor 1) hingga sangat setuju (skor 6) dengan tanpa nilai tengah. Skor mulai dari 10-60 untuk satu dimensi dan 20-120 untuk keseluruhan dimensi SWBS. Skor yang tinggi menunjukkan persepsi yang tinggi mengenai SWB dan skor rendah merefleksikan persepsi yang rendah. Alat ukur model Ellison ini cocok digunakan untuk tujuan klinis dan konseling baik untuk pribadi maupun kelompok. Alat ukur ini dapat menolong mengidentifikasi kekuatan klien mengenai pengalaman spiritual mereka (Bufford, Paloutzian \& Ellison, 1991; Ellison, 2006). Peneliti menggunakan alat ukur yang dibuat oleh Ellison dengan berbagai tujuan. Eksi \& Kardas (2017) misalnya berpendapat bahwa alat ukur ini memiliki kemampuan untuk mengukur SWB orang dewasa dengan menganalisa validitas dan pengembangan alat ukur. Ada juga peneliti yang menghubungkan SWB dengan kepemimpinan spiritual dan kepuasan kerja. SWB berpengaruh pada kepuasan kerja dan bisa juga menjadi mediator antara kepemimpinan spiritual dan kepuasan kerja (Yusof \& Mohamad, 2014). Yang sangat umum memang menghubungkan SWB dengan kesehatan mental dalam lembaga pendidikan (Jafari et al, 2010), dengan kepuasan hidup pada wanita yang mandul (Etemadifar et al, 2016), dengan depresi pada pasien dewasa yang mengindap penyakit kanker (Stutzman et al, 2017). Ada juga yang menggunakan alat ukur model Ellison ini untuk melihat hubungan SWB dengan pengungkapan diri seorang rohaniwan (Salwen et al, 2017) dan kedekatan rohani seorang imam dengan Tuhan dalam karya pelayanannya (Proeschold-Bell et al, 2014). Ada juga upaya peneliti untuk membuat standardisasi alat ukur yang diciptakan oleh Ellison untuk orang dewasa di negara tertentu seperti Yunani (Darvyri, 2014), atau adaptasi alat ukur model Ellison untuk kaum muda di Czech (Malinakova et al, 2017). 
Sementara alat ukur yang dikembangkan oleh Fisher disebut dengan Spiritual Well-Being Questionaire (SWBQ) yang dipublikasikan pada 2003. Alat ukur ini mengukur empat dimensi personal, komunal, lingkungan dan transendental dengan skala 5. Alat ukur dikembangkan berdasarkan kerangka teoretis dari Fisher sendiri. Alat ukur memiliki 20 item yang dibagi dalam empat dimensi. Maka masing-masing dimensi memiliki 5 item. Yang perlu diketahui bahwa setiap dimensi memiliki aspek pengetahuan (knowledge), inspirasi (inspiration) dan ekspresi (expression). Artinya setiap dimensi/domain SWB mengandung ketiga unsur tersebut. Alat ukur SWBQ model Fisher ini pun kerap digunakan peneliti dan melakukan adaptasi sesuai dengan keadaan negara masing-masing, seperti yang dilakukan oleh Moodley et al (2012) yang menganalisa SWB kaum muda Afrika Selatan. Lou (2015) menggunakan model Fisher untuk mengukur SWB orang dewasa tua di Cina dan intervensi apa yang relevan untuk mereka. Selain itu Dutkova et al (2017) juga mengadaptasi alat ukur Fisher untuk meneliti hubungan SWB dengan perilaku bullying pada kaum muda di Slovakia.

\section{Manfaat Teoretis dan Praktis}

Dengan menganalisa konsep model spiritual well-being dari Ellison dan Fisher ini semakin jelas bahwa terdapat perbedaan pandangan dalam diskusi mengenai spiritualitas secara umum. Spiritual Well-being merupakan ekspresi dari kesehatan spiritual seseorang. Jadi kesehatan spiritual dan spiritual well-being sebenarnya mengungkapkan unsur yang sama, yakni menyangkut kualitas relasi menusia dengan dirinya sendiri (personal), dengan orang lain (komunal), dengan sekitar (lingkungan) dan dengan hal yg transenden (transendental). Spiritual well-being tidak harus dipertentangkan dengan gagasan para psikolog tentang psychological well-being. Kendatipun kedua hal tersebut saling berhubungan satu sama lain. Bila psychological well-being fokus pada persoalan jiwa/pikiran ( $p$ syche/mind), sementara spiritual well-being dengan keempat domainnya mencakup bukan hanya masalah psikologis (kognitif/pengetahuan) tapi juga domain lainnya melewati aspek jiwa/pikiran, yakni inti paling dalam dari manusia (relasi dengan hal transenden).

Secara praktis kajian konseptual ini dapat menolong peneliti lebih memahami pendasaran teoretis yang memadai mengenai alat ukur spiritual well-being questionnaire. Kalau mau meneliti secara empiris spiritual well-being, orang dapat menggunakan alat ukur spiritual wellbeing questionnaire yang mengukur kualitas relasi seseorang dengan keempat domain: diri sendiri, komunitas, lingkungan dan hal yang transenden.

\section{KESIMPULAN DAN SARAN}

Analisa konseptual model spiritual well-being menurut Ellison dan Fisher mampu menambah perbendaharaan pemahaman teoretis mengenai SWB pada umumnya. Memang model Ellison merupakan model yang lebih dulu muncul, lalu kemudian disempurnakan dan dilengkapi oleh Fisher melalui studi dan penelitiannya selama 30 tahun terakhir. Pembahasan mereka mengenai SWB dapat menolong untuk mengerti SWB lebih komprehensif. Memang alat ukur yang mereka tawarkan senantiasa mengalami penyesuaian di tempat/negara dimana alat ukur itu dipergunakan. Namun bagaimanapun rintisan mereka berdua telah sangat menolong para peneliti untuk mengembangkan alat ukur yang lebih baik guna memahami dan mengukur spiritual wellbeing seseorang.

Jadi yang mendasari terjadinya dua model spiritual well-being adalah latar belakang biografis Ellison dan Fisher yang sama-sama memiliki latar belakang sebagai pemimpin agama. Perbedaan kedua model Ellison dan Fisher adalah dalam hal dimensi. Ellison memiliki dua dimensi sedangkan Fisher empat dimensi. Dimensi religious well-being yang mengatur 
hubungan manusia dengan Tuhan dalam Ellison merupakan dimensi transendental pada Fisher. Sementara dimensi eksistensial well-being yang mengatur hubungan manusia dengan diri sendiri dan sesamanya disebut dengan dimensi personal, komunal dan lingkungan dalam model Fisher. Lalu dampak dari ulasan konseptual model spiritual well-being menurut Ellison dan Fisher ini adalah bahwa peneliti harus memutuskan alat ukur mana yang akan digunakan dalam penelitiannya setelah melihat latar belakang dan ulasan teoretis atas kedua model ini.

Karena bahasan/studi ini bersifat kualitatif dan teoretis, maka disarankan perlu dilakukan penelitian lebih lanjut mengenai efektivitas alat ukur ini melalui penelitian empiris. Kedua, perlu dikaji dan dipelajari model-model lain sehingga dapat memperkaya kajian teoretis mengenai spiritual well-being di masa yang akan datang.

\section{Ucapan Terima Kasih}

Terimakasih disampaikan kepada Direktorat Penelitian dan Pengabdian pada Masyarakat (DPPM) Universitas Tarumanagara yang telah memberikan biaya sehingga penelitian ini bisa terlaksana dengan baik.

\section{REFERENSI}

Bakker, A., \& Zubair, A. C. (2012). Metodologi penelitian filsafat. Yogyakarta: Kanisius.

Bufford, R.K., Paloutzian, R. F., Ellison, C.W. (1991). Norms for the Spiritual Well-being Scale. Journal of Psychology and Theology, 19(1), 56-70.

Dutkova, K, Holubcikova, J, Kravcova, M, Babincak, P., Tavel, P. \& Geckova, A.M. (2017) Is spiritual well-being among adolescents associated with a lower level of bullying behaviour? The mediating effect of perceived bullying behavior of peers. Journal of Religion and Health, 56(6), 2212-2221.

Eksi, H., \& Kardas, S. (2017) Spiritual well-being: Scale development and validation. Spiritual Psychology and Counseling, 2(1),73-88.

Ellison, C. W. (1983). Spiritual well-being: Conceptualization and measurement. Journal of Psychology and Theology, 11(4), 330-340.

Ellison, L. (2006). A review of the Spiritual Well-Being scale. News Notes, 44(1).

Etemadifar, S., Hosseiny, R.S., Ziraki, A., Omrani, A., \& Alijanpoor, M. (2016) The Relationship between Spiritual Well-Being and Life Satisfaction in Famales with Infertility. Women's Health Bulletin, 3(4).

Fisher, J.W. (2010). Development and application of a spiritual well-being questionaire called SHALOM. Religions, 1, 105-121.

Fisher, J.W. (2011). The four domains model: connecting spirituality, health and well-being. Religions, 2, 17-28.

Fisher, J.W. (2016). Selecting the best version of SHALOM to acces spiritual well-being. Religions, 7, 45.

Fisher, J.W., Ng, D. (2017). Presenting a 4-Item Spiritual Well-Being Index (4-ISWBI). Religions, 8, 179.

Gomez, R; \& Fisher, J.W. (2003). Domains of spiritual well-being and development and validation of the Spiritual Well-being Questionnaire. Personality and Individual Differences, 35, 1975-1991.

Gomez, R, \& Fisher, J.W. (2005). Item response theory analysis of the spiritual well-being questionaire. Personality and Individual Differences, 38, 1107-1121.

Jafari, E., Dehshiri, G.R., Eskandari, H., Njafi, M., Heshmati, R., \& Hoseinifar, J. (2010) Spiritual well-being and mental health in university students. Procedia Social and Behavioral Sciences, 5, 1477-1481. 
Kelly, E. W. (1995). Spirituality and religion in counseling and psychoterapy. American Counseling Association.

Lou, V.W.Q. (2015). Spiritual well-being of Chinese older adults. Conceptualization, measurement and intervention. Heidelberg:Springer.

Malinakova, K., Kopcakova, J., Kolarcik, P., Geckova, A.M., Solcova, I.P., Husek, V., . . . Tavel, P. (2017). The Spiritual Well-Being Scale: Psychometric evaluation of the shortened version in Czech adolescents. Journal of Religion and Health, 56(2), 697-705.

Moodley, T., Esterhuyse, K.G.F, \& Beukes, R.B.I. (2012). Factor analysis of the spiritual wellbeing questionaire using a sample of South African adolescents. Religion \& Theology, 19, 122-151.

Paloutzian, R.F., \& Ellison, C.W. (1982). Loneliness, spiritual well-being and quality of life. In L.A. Peplau and D. Perlman (Eds), Loneliness: A sourcebook of current theory, research and therapy. New York: Wiley.

Proeschold-Bell, R.J., Yang, C., Toth, M., Rivers, M.C., Carder, K. (2014). Closeness to God among those doing God's work: A spiritual well-being measure for clergy. Journal of Religion and Health, 53, 878-894.

Salwen, E. D., Underwood, L.A. Dy-Liacco, G.S., Arveson, K.R. (2017). Self-disclosure and spiritual well-being in pastors seeking professional psychological help. Pastoral Psychology, 66, 505-521.

Yusof, J.M., \& Mohamad, M. (2014). The influence of spiritual leadership on spiritual wellbeing and job satisfaction: A conceptual framework. International Review of Management and Business Research, 3(4), 1948-1957. 